$\mathrm{PhD}$ in Technical Sciences, Associate Professor, OLENA KORNUTA Ivano-Frankivsk National Technical University of Oil and Gas Address: 15 Karpatska St., Ivano-Frankivsk, 76000, Ukraine E-mail: olenv@i.ua

Postgraduate Student, TETIANA PRYHOROVSKA Ivano-Frankivsk National Technical University of Oil and Gas Address: 15 Karpatska St., Ivano-Frankivsk, 76000, Ukraine E-mail: pryhorovska@gmail.com

\title{
PROBLEMS OF TECHNICAL STANDARDS TEACHING IN THE CONTEXT OF THE GLOBALIZATION AND EURO-INTEGRATION IN HIGHER EDUCATION SYSTEM OF UKRAINE
}

\begin{abstract}
Globalization and Ukraine association with EU imply including Ukrainian universities into the world scientific space. The aim of this article is to analyze the problem of drawing standards teaching, based on the experience of Ivano-Frankivsk National Technical University of Oil and Gas (Ukraine) and to summarize the experience of post Soviet states in a field of the new technical standards implementation. Experience of post Soviet states showed necessity to gradual transition to new standards. Based on this experience, main fundamental principles for new standards and technical regulations harmonization have been presented. The main directions of improving the system of personnel training and retraining in this field are: changing the educational institutions syllabuses to in-depth study of new standards and regulations and the skills to apply them in practice, monitoring the quality of educational programs of secondary and higher educational institutions; development of training programs for engineers and other technical personnel of basic new standards and regulations; compliance training programs and syllabuses for engineers, relevant to international training programs and syllabuses (taking into account the laws and traditions of the technical education in Ukraine); development of the national standards of education and certification on the basis of international standards.

Key words: engineering and computer graphics, technical drawing, standards and regulations, harmonization, adoption, national legislation, certifications.

\section{INTRODUCTION}

Government program provides the abandonment of obsolete Soviet standards and the introduction of 28 thousand new ones. Starting from 1 January, 2016, European and international technical regulations (normative documents) will be used in Ukraine to replace the existing national ones. Draft standards are made available to all interested parties and after a period for objection published as valid ones. To simplify the international movement of goods and to remove trade barriers, national regulations are replaced with international ones. These result in international standard definitions and descriptions, the quality requirements are standardized on a high level and movement of products can be realized worldwide.
\end{abstract}


Technical education is a complex of multi- and trans-disciplinary engineering subjects. It means that all disciplines are joined by used approaches, standards, methods, etc. They are the "coordinate system" of research and engineer thinking. Engineering thinking is not only a way of creation new idea, but the way to implement them. This ability is formed from the very beginning of studying, so subjects, studied on the first course, are very important.

Globalization and association of Ukraine with EU imply including Ukrainian universities into the world scientific space. It means that students should have information about technical standards (and draft standards in particular), actual not only in post-USSR states. Misunderstanding and misinterpretation of design documentation may have disastrous consequences.

Besides this problem is aggravated by three facts:

- students, graduated from Ivano-Frankivsk National Technical University of Oil and Gas (IFNTUOG), are interested to be employed not only in Ukraine, but at the international oil/gas prospecting companies, so international drawing standards are actual for them. Besides, often such students select teaching in English;

- today more than 500 foreign students are studying at Ivano-Frankivsk National Technical University of Oil and Gas (IFNTUOG). Most of them are from the oil/gas production states of Africa and Asia. So, they are interested to be employed at the international oil and gas producing companies and they are not going to connect their future work with post-USSR oil/gas states;

- Gazprom (Russian Federation) oil/gas prospecting activity in states of Africa and Persian Gulf in particular, causes interest of student from abovementioned states to studying of technical standards and technical regulations for oil/gas prospecting, actual in Russian Federation as post-USSR state.

So, today we have the problem of necessity to present information about two different groups of technical drawing standards: actual in post-USSR states and Ukraine in particular (USDD standards) and actual at other states (for instance, ANSI-standards). It means that information scope of "Engineer Graphics" enlarged twice with no changing of academic hours quantity.

\section{THE AIM OF THE STUDY}

The aim of this article is to analyze the problem of drawing standards teaching, based on the experience of Ivano-Frankivsk National Technical University of Oil and Gas (Ukraine) and to summarize the experience of post Soviet states in a field of the new technical standards implementation.

\section{THEORETICAL FRAMEWORK AND RESEARCH METHODS}

It worth mentioning that new technical standards implementation into educational process occurred in other post-USSR states, for example the Moldova Republic, the Baltic States. Problems of engineering graphics teaching are well analyzed at the scientific either Ukrainian or world literature. Authors always use positive experience, presented at publications of M. Helenowska-Peschke (2008), M. Mingchen (2003), C. Putz (2001), YiChing P. (2009) and others. Post Soviet states experience in a field of education modernization, presented at publications of Mahadevi S. Banad and Mahadev, Talawar (2011), V. Kushnarenko, L. Cojocari (2012), B. Horáková (2007), L. Malinovska, S. Štrausa, A. Vintere, A. Zeidmane (2009) and others. Except mentioned authors, Engineering and Computer Graphic Department staff of Ivano-Frankivsk National University of Oil and Gas (Ukraine) has own positive teaching experience, used for this manuscript. 
So, the main method of our research is the summary of the presented experience of post-Soviet states in a field of education modernization and its possible application for Ukrainian technical education modernization.

\section{RESULTS}

Traditionally, such disciplines as higher mathematics, informatics, chemistry, physics, descriptive geometry and engineer graphics are taught for first-course students. For authors, as teachers of descriptive geometry and engineer graphics, it is obvious that engineering graphics is one of the important factors of basic engineering skills and knowledge formation. Engineering graphics is the primary medium for communicating design concepts and is an important tool for analyzing engineering problems. It provides the first-year student with a background in descriptive geometry, orthographic projection and elementary geometrical figures projection, positional and metric tasks, rectification of projection (conversion of projection), surfaces, solids and their intersections; engineering drawing standards, dimensioning, detail's joints imagination, design documentation and computer-aided engineering graphics.

It is well-known, that engineering drawing is an important means of communication among engineers, technicians and professionals involved in design and production. Such uniformity is reached by the standardization and unification of drawing. "Engineering graphics" course objective is providing visualization about the objects and technical proficiency of engineer graphics. Topics covered the orthographic projection, isometric sketching, auxiliary and section views as well as dimensioning and working / assembly drawings.

Engineer graphics teaching in universities of post-USSR is sequence of mechanical engineering teaching system, developed at USSR. It worth saying, that "Engineer Graphics" course is one of the base engineer courses, so it is tough for first-year students over the world. So, there is no essential difference in teaching methods of this subject. But difference is in the content, despite of this subject is the traditional one and well-developed. First of all, Ukrainian terms and definitions of engineering graphics, which based on the Unified System of Design Documentation (USDD) standards, are not always possible to translate clearly and correctly into English. This system of standards was developed in USSR and today is actual for post-USSR states. Ukrainian national standards, based on the standards of the former USSR, are different from drawings standard, actual for the United States and European states (for example, ANSI-standards). In particular, examples are drawing sheet formats, title blocks and their completing, hatching, drawing symbol system, views placing, dimensioning, roughness, etc. Besides, such topics as projection drawing, thread and thread joints marking, lettering, sketching, assembly drawings and design documentation execution differ significantly in Ukraine and in English-speaking states. Since, as it was mentioned above, foreign students study by the same syllabuses as Ukrainian ones, so studying of drawing standards, actual in English-speaking states, was not provided. So, directing student to working with standards, we observe complete lack of English versions of actual standards and some relevant drawing terms. It is one of the main problems in this subject teaching.

The department of Engineering and Computer Graphics of Ivano-Frankivsk National Technical University of Oil and Gas has developed "Engineering and Computer Graphics" course by the actual Unified System of Design Documentation and teach foreign students the course in English, which is a compromise decision.

Problem of drawing standards teaching is linked with the problem of CAD teaching. Drawing Editors such as Kompas, AutoCAD provide embedded drawing standards (for 
instance, dimensioning, types of lines, title blocks, etc.) and have embedded libraries of standardized details like fasteners. Sense of computer lessons is graphic editors (Kompas, AutoCad) studying. These labs cover the fundamentals of technical drawing and introduce computer-aided design (CAD) with a focus on mechanical applications. Students study "Kompas" as a part of "Engineering and Computer Graphics" course. Topics include geometrical drawing, spatial modeling and embedded libraries usage. AutoCad is studied as a part of another course. Draft standards, technical regulations changing will cause changes not only in "Engineer Graphics" course teaching. Obviously, it will cause changes in all technical and specialized disciplines. Experience of IFNTUOG shows, what information students should have about technical standards (and drawing standards in particular): ISO, USDD and ANSI, despite lack of teaching hours for "Engineer and Computer Graphics" course. That's why we had a problem of studying intensification and stimulation student's motivation by different means.

This information is presented on every lection. Increasing of information scope leads to lecture's structure changes, student's individual work increasing, needs more preparedness of a teacher and different means of visualization and knowledge digestibility usage, development problems for solving, relevant to future work tasks. As it was mentioned above, the way of new technical standards implementation into educational process was passed by other post Soviet states, for example the Moldova Republic and the Baltic States. Their experience showed such fundamental principles for new standards and technical regulations harmonization:

- new technical standards implementation and legislative harmonization are limited to essential safety requirements (or other requirements in the general interest) with which products put on the market must conform and can therefore enjoy free movement throughout the European Union (Kushnarenko, Cojocari, 2012);

- the task of drawing up technical production specifications is entrusted to organizations competent in industrial standardization, which take the current stage of technology into account when doing so;

- these technical specifications are not mandatory and maintain their status of voluntary standards (Yi-Ching, 2009);

- the authorities are obliged to recognize that products manufactured in conformity with harmonized standards are presumed to conform to the essential requirements established by the Directive. If the producer does not manufacture in conformity with these standards, he has an obligation to prove that his products conform to the essential requirements (Mahadevi, Mahadev, 2011).

Experience of these state showed necessity to gradual transition to new standards. The state's attitude to the different formats usually was advisory and was accompanied by the evaluation characteristics of the species - "recommended", "obsolete", "under observation for adoption" and so on. This ensures that temporary reserves required for developers of public information systems. For example, changing the characteristics of the standard from "recommended" to "legacy" is a signal to developers on the revision of this standard, however, remains sufficient time for the normal functioning of existing systems. Government agencies responsible for the development of such documents dynamically track the status of standards and promptly make the appropriate adjustments. Besides, process of technical standards and regulations changing were not simultaneous, it took some years for Poland, the Moldova Republic, the Baltic States. Such time lag made possible gradual retraining of universities staff. 
At the same time national legislation was reformed. The law introduces new terminology, giving the modern content of the main items. It has been working actively to improve the skills of teachers and university professors. Special training manuals were also developed. Generally, technical standards and regulations were in open access and free for all persons. Quite often new standards and regulations presentations included appendixes with comparing tables to see changes. Generally, national concepts of technical standards and regulations adoption and harmonization were developed. Special attention was paid to training of universities staff, engineers, and designers, in particular:

- understanding and explanation of the standards adoption and harmonization purposes;

- developments of the information usage skills to manage the economic entity and the implementation of good corporate governance;

- development of technical information processing skills (Mahadevi, Mahadev, 2011).

- formation of a new approach to the application of standards and other regulations (Evans, Goodnick, Roede, 2003).

The main directions as for improving the system of personnel training and retraining in this field were:

- changing of the educational institutions syllabuses to in-depth study of new standards and regulations and the skills to apply them in practice,

- monitoring the educational programs quality of secondary and higher educational institutions;

- development of training programs for engineers and other technical personnel of basic new standards and regulations;

- compliance training programs and syllabuses for engineers, relevant to international training programs and syllabuses (taking into account the laws and traditions of the technical education in Ukraine);

- development of the national standards of education and certification on the basis of international standards (Yi-Ching, 2009).

These are so-called basic principles of training. We believe that they fully meet all the requirements of international educational standards in the field of engineering. So, it is very important to develop the national concepts of technical standards and regulations adoption and harmonization, highlighting "Training and education" section, accorded with the Bologna agreement in the sphere of educational activities.

One can argue about the appropriateness and the transition necessity of our higher education in such a system, but as they say the process has already started and a lot of work in this direction, i.e. the universities, after the approval of the State educational standard, will begin to develop their own curricula and programs for all courses and disciplines (Horáková, 2007).

\section{CONCLUSIONS}

The process of globalization accompanies with the formation of educational and scientific space and the development of uniform standards and criteria. Ukraine, in accordance with the requirements of the Bologna process must complete the modernization of higher education on the basis of information and communication technologies. Its purpose is to ensure the mobility and competitiveness of graduates in the global market economy. Technical education must be able to respond to rising student expectations and the demands of global competition.

Experience of post Soviet states has showed the necessity of gradual transition to new standards and national legislation. It means that transferring should not be 
simultaneous, standards and regulations should be in open access and free for all persons. Familiarization with different systems of standards will increase the competitiveness of students in the labour market. However, for technical education it is necessary to change and correct content of disciplines, new teaching methods that will make the transition process of learning new technical standards more harmonious.

Based on post Soviet states experience, the perspective research tendencies for Ukraine educational system are the following: development programs of standards adoption and harmonization; training programs for universities staff development; extension of the syllabuses to in-depth study of new standards and regulations and the skills to apply them in practice; monitoring of research achievements in this field of post Soviet states; development of the national standards of education and certification on the basis of international standards.

\section{REFERENCES}

1. Evans, D. L., Goodnick, S. M. \& R., Roede, J. (2003). ECE Curriculum in 2013 and Beyond: Vision for a Metropolitan Public Research University. IEEE Transactions on Education, Vol. 46, No 4, p. 420-428.

2. Helenowska-Peschke, M. (2008). Multimedia manuals for descriptive geometry and engineering graphics. The Journal of Polish Society for Geometry and Engineering Graphics, No 18, p. 44-50.

3. Horáková, B. (2007) Current principles and importance of technical harmonization in the EU for technical standardization. GeoScience Engineering, Volume LIII, No 1, p. 36-52.

4. Kushnarenko, V., Cojocari, L. (2012). Internationalization of Higher Education in Post-Soviet Small States: Realities and Perspectives of Moldova. Current Issues in Comparative Education, Teachers College, Columbia University, No 15(1), p.132-144.

5. Mahadevi, S. Banad, Mahadev, Talawar. (2011). Impact of Globalization on Indian Technical Education System, New Knowledge in a New Era of Globalization. Retrieved: 01.01.2015 from : http://www.intechopen.com/books/newknowle dge-in-a-new-era-of globalization/impact-of-globalization-on-indian-technical-educationsystem.

6. Malinovska, L., Štrausa, S., Vintere, A., Zeidmane, A. (2009). How best to educate the future engineers. In: Proceedings of the Engineering for rural development conference. Jelgava, 28.-29.05.2009, p. 58-65.

7. Mingchen, M. et al. (2003). The Discussion on the Reformation of Engineering Graphics Education. Research in Teaching, No 28(3), p. 225-228.

8. Putz, C. (2001). Teaching descriptive geometry for architects: didactic principles and effective methods demonstrated by the example of Monge projection. In: Proceedings of the 15-th Simposio Nacional de Geometria Descritiva e Desenho Tecnico IV International Conference on Graphics Engineering for Arts and Design (5-9.11.2001). Sao Paulo, p. 269-278.

9. Yi-Ching, P. (2009). A review of washback and its pedagogical implications. VNU Journal of Science, Foreign Languages, No 25, p. 257-263. 